\title{
Radiocarbon
}

1963

\section{UCLA RADIOCARBON DATES II}

\author{
G. J. FERGUSSON and W. F. LIBBY
}

Institute of Geophysics, University of California, Los Angeles 24, California

The measurements reported in this list have been made in the Isotope Laboratory at the Institute of Geophysics, UCLA during 1962. Dates have been calculated on the $\mathrm{C}^{14}$ half life of 5568 years and using 95\% NBS oxalic acid as modern standard, in agreement with the decision of the Fifth Radiocarbon Dating Conference (Godwin, 1962).

\section{ACKNOWLEDGMENTS}

We are indebted to the National Science Foundation for Grant G-14287 for financial support for this work, and also acknowledge the excellent assistance of Ervin Taylor and Carleton Hoel with laboratory work.

\section{SAMPLE DESCRIPTIONS}

\section{A. United States}

\section{UCLA-131. Ash Cave, Washington}

Charcoal and charred midden material from hearth at Ash Cave (45WW61) in the lower Snake River canyon, Walla Walla County, Washington $\left(46^{\circ} 33^{\prime} \mathrm{N}\right.$ Lat, $118^{\circ} 33^{\prime} \mathrm{W}$ Long). Hearth was located at surface of a deep midden deposit (Stratum 3) mantled by a layer of Mt. Mazama ash (Stratum 2 ). Enclosed in the midden deposit were remains typical of the Old Cordilleran culture in the Pacific Northwest (Butler, 1961). Coll. 1958 by B. R. Butler; subm. by E. H. Swanson Jr., Idaho State College Mus. Comment (B.R.B.) : Mt. Mazama ash separates Old Cordilleran culture components from the subsequent Cold Springs horizon at various sites in the Columbia Plateau; the Ash Cave date provides a terminus ante quem date for this geologic horizon marker and for the Cold Springs horizon in the Columbia Plateau.

\section{Birch Creek Valley series, Idaho}

Charcoal from two large rockshelters, Veratic and Bison caves, near Blue Dome in the Birch Creek Valley of eastern Idaho $\left(44^{\circ} 05^{\prime} \mathrm{N}\right.$ Lat, $112^{\circ} 55^{\prime} \mathrm{W}$ Long). Both caves were continuously occupied from late Anathermal to early historic times. Veratic Cave is located at the base of an alluvial fan, and Bison Cave is located near the top of the same fan. The physical stratigraphy at Veratic Cave is complex, but the deposits at Bison Cave can be grouped into 
five major units: (1) Birch Creek sediments, the earliest; (2) Fan Gravel I, a thick deposit with Mt. Mazama ash enclosed near its surface; (3) Yellow Sandy Loam I, a long sequence of sandy loam sediments; (4) Fan Gravel II, which resembles Fan Gravel I; (5) Yellow Sandy Loam II, which resembles Yellow Sandy Loam I. It is believed that Fan Gravel I represents the onset of the Altithermal, and that Yellow Sandy Loam I continued to near the end of the Altithermal. Fan Gravel II may mark the end of the Altithermal, with the Yellow Sandy Loam II series representing Medithermal deposits. The Birch Creek deposit, which is also at the base of Veratic Cave sequence, is probably late Anathermal in time. Occupation at Bison Cave begins at the surface of the Birch Creek deposit and continues to the surface of Yellow Sandy Loam II. Fan Gravel II artifact inventory is meager, while Yellow Sandy Loam II contains a rich inventory of cultural remains. Occupation at Veratic Cave has also been continuous from the surface of the Birch Creek deposits to the present surface. However, unlike Bison Cave, the earliest occupation is represented by a very rich accumulation of cultural materials, while the later has a meager cultural inventory. Hence correlation of the culture sequences is largely dependent on $\mathrm{C}^{14}$ dates. Coll. and subm. by E. H. Swanson Jr.

\section{UCLA-220. Bison Cave \\ $2350 \pm 120$ \\ 400 B.c.} and 15.

Feature 12, earth oven intrusive from Level 12, penetrates Levels 13, 14 .

\section{UCLA-219. Bison Cave}

$2960 \pm 100$

1010 в.с.

Feature 9, earth oven intrusive from Level 16, bedded on Level 16a.

\section{UCLA-130. Bison Cave}

$3360 \pm 100$

1410 в.C.

Feature 14, earth oven intrusive from surface of Level 16b, bedded on Level 17. Comment (E.H.S.) : the earth ovens were located one above the other in a close sequence at the bottom half of Yellow Sandy Loam II. Dates are in proper sequence and indicate that repeated construction of earth ovens has not upset the stratigraphy; they also support our previous interpretation of the Medithermal age of Yellow Sandy Loam II.

UCLA-217. Veratic Cave

Feature I, hearth intrusive into Level 21 from hase of Level 19 or surface of Level 20.

UCLA-160. Veratic Cave

$$
\mathbf{1 5 8 0} \pm \mathbf{8 0}
$$

Charcoal from Level 22.

A.D. 370

$$
\begin{aligned}
& 2920 \pm 120 \\
& 970 \text { в.c. }
\end{aligned}
$$

Feature 8, earth oven associated with Level 26.

\section{UCLA-162. Veratic Cave}

Feature 5, hearth associated with Level 29.
$5670 \pm 120$

3720 в.c. 
UCLA-161. Veratic Cave

$5870 \pm 120$

Charcoal from Level 29.

3920 в.C.

General Comment (E.H.S.) : the $\mathrm{C}^{14}$ dates from Veratic Cave are in stratigraphic order and check the evaluation of the finely stratified sediments at the site. The overlap in the $\mathrm{C}^{14}$ dates from the two sites will permit establishment of a composite continuous cultural sequence. The two series of $\mathrm{C}^{14}$ dates confirm in broad outline previous estimates of the geologic age of the deposits at the site and show that the bulk of the alluvial fan deposits are Altithermal in age. They will also be useful for evaluation of the deposits and the attendant depositional processes. Side notched points occur below the two earliest dated horizons at Veratic Cave and continue in an unbroken sequence into the historic deposits at both sites. This cultural continuum, of considerable significance in northwestern prehistory, could not have been so clearly established without $\mathrm{C}^{14}$ dates.

\section{Lorenzen series, Modoc County, California}

Charcoal samples from Pit M-11, Lorenzen Site, Modoc County, California. Site is a deep, stratified deposit which includes at its lowest levels Cascade point artifacts. Coll. and subm. by M. A. Baumhoff, Univ. of California, Davis, California.

UCLA-126. Lorenzen Site, 18 in. depth

UCLA-125. Lorenzen Site, 48 in. depth

\section{UCLA-127. Lorenzen Site, 75 in. depth}

$$
\begin{array}{r}
390 \pm 70 \\
\text { A.D. } 1560 \\
1470 \pm 60 \\
\text { A.D. } 480 \\
3300 \pm 100 \\
1350 \text { B.C. }
\end{array}
$$

General Comment (M.A.B.) : the date sequence is within the expected range. The deepest sample (UCLA-127) appears to be near the beginning of the Achumawi-Atsugewi occupation, for which our current work on glottochronology indicates an age of 3100-3500 yr.

\section{Canada Verde series, Santa Rosa Island, California}

Three separate cultures are recognized on Santa Rosa Island, the earliest being the Dunedweller, followed by Highland and finally the Canalino. Some of the stratified sites contain remains of more than one culture. The site at Canada Verde, on the north central coast $\left(34^{\circ} 01^{\prime} 31^{\prime \prime} \mathrm{N}\right.$ Lat, $120^{\circ} 08^{\prime} 05^{\prime \prime}$ W Long), is ca. $35 \mathrm{ft}$ above sealevel, covers $1200 \mathrm{yds}$ in length and is ca. $30 \mathrm{ft}$ deep. The site contains four cemeteries in which several hundred skeletons have been found. A great number of artifacts have been found with the burials, including a number of points of Gypsum Cave type. Coll. by P. C. Orr and B. White; subm. by P. C. Orr, Santa Barbara Mus. of Nat. History, Santa Barbara, California.

UCLA-137.

$3250 \pm 140$

1300 в.c.

Charcoal from hearth, $50 \mathrm{ft} \mathrm{W}$ of stake of Blackbottom Cemetery A. Depth 12 in. beneath an eroded midden. 
UCLA-179.

$$
3020 \pm 100
$$

1070 в.c.

Shell necklace (Cyprea) from burial No. 94 in Blackbottom Cemetery.

UCLA-138.

$3420 \pm 100$

1470 в.C.

Shell (Mytilus californianus) from eroded midden above UCLA-137.

UCLA-139.

$3240 \pm 120$

Shell (Haliotis rufescens) from same eroded midden as UCLA-138.

UCLA-140.

$4260 \pm 90$

2310 в.c.

Charcoal from Cemetery X, with burial at depth of 83 in. Sample in clean sand, below two strata of black midden, each separated by windblown sand. Comment (P.C.O.) : UCLA-137, 138, 139 and 140 occupy the upper strata of a Dunedweller site and were originally regarded as late Dunedweller. However, the above dates signify a transitional period between late Highland and early Canalino cultures (Orr, 1960a).

\section{Canalino Culture series, Santa Rosa Island, California}

The prehistoric Canalino Culture was the last Indian culture on Santa Rosa Island, $35 \mathrm{mi}$ off Santa Barbara, California. The following samples are from Cemetery A at Skull Gulch on the northwestern coast of the island $\left(34^{\circ}\right.$ $00^{\prime} 15^{\prime \prime} \mathrm{N}$ Lat, $120^{\circ} 11^{\prime} 40^{\prime \prime} \mathrm{W}$ Long). The site is large, occupying both sides of the gulch and comprising 73 house sites and three known cemeteries. Some of the cemeteries have been exposed by the erosion of the gulch, and the others discovered by trenching (Orr, 1956, 1960a). One previous date on this cemetery, UCLA-134, $330 \pm 50$ (UCLA I), was inconsistent with the stratigraphy of the site, and the following samples were run to check the age of Cemetery $A$ which was expected to be 2500 to $3000 \mathrm{yr}$. Subm. by P. C. Orr.

UCLA-135.

$$
1820 \pm 90
$$

$$
\text { A.D. } 130
$$

Shell (Mytilus californianus) from midden over Cemetery A.

UCLA-178.

$$
\text { A.D. } 1050
$$

$$
900 \pm 100
$$

Shell beads (Olivella biplacata) screened from about the burials in Trench $4 \mathrm{~B}$, Level 2 of Cemetery A. Comment (P.C.O.) : it seems unlikely that this small cemetery was in use for $900 \mathrm{yr}$; therefore it appears that one or perhaps both of these dates are in error.

\section{UCLA-142. Tecolote Point, Santa Rosa Island, $\quad 4000 \pm 120$ California \\ 2050 B.C.}

Shell (Mytilus californianus) from depth of $3 \mathrm{ft}$ in midden overlying Cemetery A $\left(34^{\circ} 00^{\prime} 25^{\prime \prime} \mathrm{N}\right.$ Lat, $120^{\circ} 10^{\prime} 55^{\prime \prime} \mathrm{W}$ Long). Cemetery A represents the Red Head phase of the Dune Dweller culture dated as $7070 \pm 300$ (L-290-D, Lamont IV). Coll. by P. C. Orr and B. White; subm. by P. C. Orr. Comment (P.C.O.) : it appears as though occupation of this site and other 
coastal areas was interrupted for up to $3000 \mathrm{yr}$ during the period when the Highland culture was the dominant one on the island. (UCLA-105, UCLA I). The abandonment of coastal areas is probably also related to climate since it coincides with the "little pluvial" 4-6000 yr ago when rainfall was greater than at present.

UCLA-144. Santa Cruz Island, California $\quad 14,200 \pm 250$

12,250 B.C.
Wood from large log of Douglas Fir buried in cut bank of creek in Santa Cruz Island Formation ( $34^{\circ} 0^{\prime} 12^{\prime \prime} \mathrm{N}$ Lat, $119^{\circ} 52^{\prime} 30^{\prime \prime} \mathrm{W}$ Long). Coll. by Clifton Smith; subm. by P. C. Orr. Comment (P.C.O.) : age compares well with L-244, 15,820 \pm 280 (Lamont IV) and confirms that the Santa Rosa Island Formation (Orr, 1960b) and the Santa Cruz Island Formation (Chaney and Mason, 1934) are of late Wisconsin and essentially equivalent.

\section{San Nicolas Island series, California}

San Nicolas Island ( $33^{\circ} 15^{\prime} \mathrm{N}$ Lat, $119^{\circ} 30^{\prime} \mathrm{W}$ Long), is one of a group of eight islands lying off the coast of Southern California. The island is ca. 8 mi long and $4 \mathrm{mi}$ wide. More than 50 occupation sites are known-more com. plete details are given by Reinman and Townsend (1960) and Meighan and Eberhart (1953).

\section{UCLA-147. San Nicolas Island, Site 40}

Shell beads (Olivella) from two graves at Site SNI-40 on the northwestern side of the island. The burial area is on the inland slope of the dune and the burials were all found in sterile sand, with the midden seemingly skirting the edge of the area. Coll. by F. Reinman and S. Townsend; subm. by C. W. Meighan, Anthropol. Dept., UCLA.

\section{UCLA-165. San Nicolas Island, Site 16}

$$
\begin{aligned}
& 3300 \pm 100 \\
& 1350 \text { в.C. }
\end{aligned}
$$

Shells (Haliotis) associated with burial at Site SNI-16 on the northwestern side of the island. The burial area was on the leeward side of the dune and shells and top of skull were only a few inches below surface of the sand. Coll. by F. Reinman and S. Townsend; subm. by C. W. Meighan.

\section{UCLA-164. San Nicolas Island, Site 18 \\ A.D. 1650 \\ $300 \pm 60$}

Roughed-out blanks (Haliotis) for manufacture of shell fish-hooks from Site SNI-18 on extreme northwestern end of the island. It is a very high dune site which overlooks the beach to the $\mathrm{N}$ and to the $\mathrm{W}$. Largest remaining site on the island. Coll. by F. Reinman and S. Townsend; subm. by C. W. Meighan.

\section{UCLA-195. San Nicolas Island, Site 51}

$$
\begin{gathered}
2550 \pm 80 \\
600 \text { в.c. }
\end{gathered}
$$

Shell (Mytilus californianus) from Site SNI-51. From stratum at depth of $6 \mathrm{ft}$ which contained some woven sea grass, cordage and a stone scraping tool. Deepest known occurrence of woven sea grass. Evidence of human habitation extends down to $7.5 \mathrm{ft}$. Subm. by C. Rozaire, Southwest Mus., Los
Angeles. 


\section{UCLA-196. San Nicolas Island, Site 51}

$$
3170 \pm 90
$$

Shell (Mytilus californianus and Haliotis cracherodii) from Site SNI-51 at depth of 7 to $7.5 \mathrm{ft}$. Bottom layers of deposit. Subm. by C. Rozaire.

\section{UCLA-197. San Nicolas Island, Site 51}

$\mathbf{2 4 4 0} \pm \mathbf{8 0}$ 490 в.c.

Charcoal from a cremation, Site SNI 51. Subm. by C. Rozaire. General Comment: San Nicolas Island has been inhabited by maritime people for at least $4000 \mathrm{yr}$. The inhabitants must have had reasonably adequate boats, not only to make the channel crossing but for fishing and sea mammal hunting, as there is evidence from midden refuse that the economy was based on seafaring activities. This is therefore a good area to learn more about the transition from land-oriented to sea-oriented cultures.

\section{Lake LeConte series, California}

Samples bearing on paleohydrography and paleoecology of Lake LeConte. Subm. by C. L. Hubbs, Scripps Inst. of Oceanography, La Jolla, California.

\section{UCLA-189. Lake LeConte}

$32,200 \pm 2000$ 30,250 в.c.

Clam shells (Rangia) representing an old brackish-water stage of the lake ( $33^{\circ} 22^{\prime} 12^{\prime \prime} \mathrm{N}$ Lat, $115^{\circ} 47^{\prime} 55^{\prime \prime}$ W Long).

\section{UCLA-190. Lake LeConte}

$3970 \pm 100$

2020 в.c.

Clam shells (Tagelus) representing a fairly recent marine stage of the lake ( $33^{\circ} 22^{\prime} 12^{\prime \prime} \mathrm{N}$ Lat, $115^{\circ} 47^{\prime} 55^{\prime \prime} \mathrm{W}$ Long).

\section{UCLA-191. Lake LeConte}

\section{$>34,000$}

Clam shells (Chione) from the very surface of the exposed lake bottom, where many of these clams occur in paired valves, indicating in situ deposit under marine conditions. Alt $160 \mathrm{ft}$ below mean sealevel $\left(33^{\circ} 23^{\prime} 32^{\prime \prime} \mathrm{N}\right.$ Lat, $115^{\circ} 42^{\prime} 00^{\prime \prime}$ W Long).

\section{UCLA-192. Lake LeConte}

$$
\begin{aligned}
270 & \pm 60 \\
1680 & \text { в.c. }
\end{aligned}
$$

Charcoal from hearths containing freshwater-fish bones. Alt $160 \mathrm{ft}$ below mean sealevel ( $33^{\circ} 23^{\prime} 21^{\prime \prime} \mathrm{N}$ Lat, $115^{\circ} 42^{\prime} 12^{\prime \prime}$ W Long).

\section{UCLA-200. Painted Cave, Baja California}

$$
\mathbf{5 3 0} \pm \mathbf{8 0}
$$

\section{A.D. 1420}

Wooden peg from rock crevice in large rock shelter in central Baja California $\left(27^{\circ} 38^{\prime} \mathrm{N} \mathrm{Lat}, 112^{\circ} 58^{\prime} \mathrm{W}\right.$ Long $)$. The shelter contains over 135 large painted full sized figures of humans and animals done in red, black and white. The paintings are pre-Spanish. The peg is presumed to be associated with the wall paintings. Coll. and subm. by C. W. Meighan, Anthropol. Dept., UCLA. Comment (C.W.M.) : associated cultural remains belong to the Comondú culture. It is believed that the paintings are associated with the same culture. 


\section{UCLA-249. Chumash Painted Cave, Santa Barbara, $<2000$} California

Sample of the paint from about two square feet of solidly painted surface in the Chumash Pictograph Shelter at Hurricane Deck near Santa Barbara, California. It consisted of disintegrated sandstone with some small amount of charcoal which was only $1 / 20$ of the normal amount needed. Coll. by Campbell Grant, Santa Barbara Mus. of Nat. History, Santa Barbara, California. Comment: within the large error it appears to be young, certainly not over $2000 \mathrm{yr}$ old. Date similar to Painted Cave from Baja California (UCLA-200), although the Chumash paintings are part of the Canalino culture.

\section{UCLA-124. Falcon Hill, Nevada}

$$
\begin{array}{r}
1860 \pm 70 \\
\text { A.D. } 90
\end{array}
$$

Coiled basketry fragment from Shrub-ox shelter at Falcon Hill near N shore of Pyramid Lake, Nevada $\left(40^{\circ} 19^{\prime} \mathrm{N}\right.$ Lat, $119^{\circ} 21^{\prime} \mathrm{W}$ Long). This site has the first find of the Shrub-ox (Euceratherium) in Nevada, although it is well known from late-Pleistocene fauna of certain caves in northern California. The basketry came from the second lowest level of the site at Area 2, depth 36 to 42 in. Coll. and subm. by Richard Shutler, Jr., Nevada State Mus., Nevada. Comment: date places sample in late Lovelock Culture.

\section{Frenchman Flat series, Nevada}

Plant remains from abandoned nests of packrat in the creosote-bush zone surrounding Frenchman Flat, Nevada. Subm. by P. V. Wells, New Mexico Highlands Univ., Las Vegas, New Mexico.

\section{UCLA-150. Ranger Mountain}

\section{6,950 в.C.}

Twig (Juniperus osteosperma) alt $3500 \mathrm{ft}$ on Ranger Mountain $\left(36^{\circ} 47^{\prime}\right.$ $\mathrm{N}$ Lat, $115^{\circ} 53^{\prime} \mathrm{W}$ Long).

\section{UCLA-151. Spotted Range}

Twig (Juniperus osteosperma) alt $5000 \mathrm{ft}$ on Spotted Range $\left(36^{\circ} 39^{\prime} \mathrm{N}\right.$ Lat, $115^{\circ} 56^{\prime} \mathrm{W}$ Long). Comment: should be compared with previous dating from Ranger Mountain, UCLA-107, 10,000 \pm 160 (UCLA I). Presence of juniper at $3500 \mathrm{ft}$ implies rainfall of 10 to 15 in. per yr, compared to less than 5 in. at present.

\section{Grants series, New Mexico}

Samples from aboriginal hearths in the vicinity of Grants, New Mexico. These pre-ceramic sites are exposed by modern arroyos dissecting alluvium and colian sand. While only non-diagnostic artifacts were found in association with the hearths it is believed that their ages span the time of occupation of the San Jose valley by makers of San Jose and Lobo projectile points as described by Bryan and Toulouse (1943). Coll. and subm. by G. A. Agogino, Baylor Univ., Waco, Texas, and C. V. Haynes, Univ. of Arizona, Tucson.

\section{UCLA-221. Grants Arroyo Site 36}

$$
5170 \pm 400
$$

Charcoal from hearth in alluvium. Hearth exposed in arroyo wall ca. $3 \mathrm{ft}$ below surface, $2 \mathrm{ft}$ above erosional disconformity on red eolian sand and as- 
sociated with numerous flint and pitchstone flakes $\left(35^{\circ} 11^{\prime} 28^{\prime \prime} \mathrm{N}\right.$ Lat, $108^{\circ}$ $52^{\prime} 29^{\prime \prime}$ W Long).

\section{UCLA-222. Grants Arroyo Site 5}

Charcoal from large hearth in the alluvium exposed in arroyo wall ca. 6 $\mathrm{ft}$ below surface and $1 \mathrm{ft}$ above erosional disconformity on red eolian sand. Two sandstone slab milling stones occurred inverted on the hearth $\left(35^{\circ} 11^{\prime} 30^{\prime \prime} \mathrm{N}\right.$ Lat, $108^{\circ} 52^{\prime} 31^{\prime \prime}$ W Long).

\section{UCLA-223. Grants Arroyo Site 7 \\ $4075 \pm 100$ \\ 2125 B.c.}

Charcoal from large hearth near base of alluvium exposed in modern arroyo wall ca. $11 \mathrm{ft}$ below surface and $1 \mathrm{ft}$ above erosional disconformity on red eolian sand. Tip of a projectile point and numerous flint flakes found in direct association with hearth ( $37^{\circ} 7^{\prime} 8^{\prime \prime} \mathrm{N}$ Lat, $107^{\circ} 47^{\prime} 22^{\prime \prime}$ W Long).

\section{UCLA-224. Grants Arroyo Site 9 U $\quad 7110 \pm 270$ \\ 5160 в.c.}

Charcoal from upper of two charcoal lenses in red eolian sand exposed in arroyo wall and occurring $3 \mathrm{ft}$ below surface. No associated artifacts $\left(35^{\circ} 7^{\prime}\right.$ $10^{\prime \prime}$ N Lat, $107^{\circ} 47^{\prime} 38^{\prime \prime}$ W Long).

\section{UCLA-225. Grants Arroyo Site 9 L}

$7200 \pm 150$

Charcoal from charcoal lens $5 \mathrm{ft}$ below UCLA-224.

\section{UCLA-226. Grants Arroyo Site 12}

Charcoal from hearths in alluvium exposed near head of modern arroyo $0.75 \mathrm{mi} \mathrm{N}$ of Grants 1 site of Bryan and Toulouse (1943). Numerous flint flakes found in association ( $35^{\prime \prime} 11^{\prime} 30^{\circ} \mathrm{N}$ Lat, $107^{\circ} 47^{\prime} 55^{\prime \prime} \mathrm{W}$ Long).

\section{Ohio-Adena, Hopewell series, Ohio}

Samples from Adena and Hopewell sites in Ross County and Hocking County, Ohio. Coll. and subm. by F. J. Soday, Skelly Oil Co., Tulsa, Oklahoma.

\section{UCLA-241. Thurman DeLong Mound, Adelphi $1900 \pm 100$ A.D. 50}

Charcoal from Adena mound, 4 mi SW of Adelphi, Ross County, Ohio $\left(39^{\circ} 25^{\prime} \mathrm{N}\right.$ Lat, $82^{\circ} 48^{\prime} \mathrm{W}$ Long). Ohio State Mus. Site Ro83; FJS Site 610. This mound contained an unusual rock layer which covered $1200 \mathrm{sq} f t$ and contained 7970 fire cracked rocks weighing $782 \mathrm{lbs}$. Underneath it was a puddled clay layer 6 in. thick covering $100 \mathrm{sq} \mathrm{ft}$. With the exception of the adjacent John Luckhart mound, this rock layer is a unique feature in Adena mounds. The cultural inventory also was unusual, and included two bone needles. Sample was obtained in a fired area near a deposit of cremated human bones in the center of the mound, below the rock and puddled clay layers, and ca. $10 \mathrm{ft}$ from the top of the mound.

UCLA-242A. Earl DeLong Mound, Laurelville $1825 \pm 70$ 


\section{UCLA-242B. Earl DeLong Mound, Laurelville}

$$
1938 \pm 75
$$

A.D. 12

Charcoal from Adena mound, Laurelville, Hocking County, Ohio (39 28' N Lat, $82^{\circ} 44^{\prime}$ W Long). FJS Site 612. This Adena mound contained a number of burials and an extensive deposit of cremated human bones. One of the well-preserved skeletons had a stone earspool at the left side of the skull and a projectile point at the right side of the skull. The earspool was similar to the elaborate copper, stone, and wood earspools so characteristic of the Hopewell culture. Sample from depth of $5 \mathrm{ft}$, adjacent to the cremation area and the burial with the earspool. UCLA-242A and $242 \mathrm{~B}$ are duplicate collections.

\section{0 в.c.}

Charcoal from Adena mound, Frankfort, Ross County, Ohio (39 $24^{\prime} \mathrm{N}$ Lat, $83^{\circ} 11^{\prime}$ W Long). FJS Site 671. It contained two cremation deposits, a tightly flexed burial with a spearpoint within the rib cage, and other burials. It was constructed from an extremely hard clay (practically unburned brick) which is unusual for this area. Sample from Fireplace 1 at the base of the mound, 52 in. below the surface.

\section{UCLA-244A. Russell Brown No. 1, Chillicothe $1750 \pm 80$ A.D. 200 \\ UCLA-244B. Russell Brown No. 1, Chillicothe \\ $2090 \pm 70$}

Charcoal from Hopewell mound, Chillicothe, Ross County, Ohio ( $39^{\circ} 20^{\prime}$ N Lat, $82^{\circ} 58^{\prime}$ W Long). FJS Site 613 . This site was presumably associated with the Harness Works, a classic Hopewell center on the Scioto River E of Chillicothe. The first survey was by Squier and Davis in 1850, at which time it comprised a large mound, a large circular enclosure (1750 ft in diam), a square enclosure, and 11 smaller mounds. Mound No. 1 was one of the small mounds. It contained the remains of a well-defined circular habitation structure, $30 \mathrm{ft}$ in diam, and a cremation area filling the house structure. Numerous artifacts were present. The structure may have served as a cremation area for the main Harness mound. UCLA-244A was from Fireplace 210, depth 16 in., and UCLA-244B was from the cremation layer near a large classic Hopewell pottery vessel fragment, depth 24 in.

\section{UCLA-245. Russell Brown No. 2, Chillicothe $\quad 2720 \pm 90$ 790 в.C.}

Charcoal from Hopewell mound, Chillicothe, Ross County, Ohio $\left(39^{\circ} 20^{\prime}\right.$ N Lat, $82^{\circ} 58^{\prime}$ W Long). FJS Site 615. Although adjacent to Russell Brown No. 1 , the structure of this mound was very different. In a rectangular habitation structure some cremation had been practiced, but less than that in Mound 1. The main feature was a large deposit of fire fractured square based knives made both from Flint Ridge flint and from nodular flint. Several large flint cores and an abundance of flake knives also were found. Sample was from a fireplace at the base of the mound, $22 \mathrm{in.} \mathrm{depth.}$

UCLA-264A. Russell Brown No. 3, Chillicothe $\begin{aligned} 1335 & \pm 70 \\ \text { A.D. } 615 & \end{aligned}$ 


\section{UCLA-246B. Russell Brown No. 3, Chillicothe

Charcoal from Hopewell mound, Chillicothe, Ross County, Ohio $\left(39^{\circ} 20^{\prime}\right.$ $\mathrm{N}$ Lat, $82^{\circ} 58^{\prime} \mathrm{W}$ Long). FJS Site 663 . This mound also differed in structure and contents from adjacent mounds 1 and 2 . It contained only a minor cremation area, and showed no evidences of any habitation. A rectangular copper breastplate with associated textile material was found, but its main characteristic was numerous deposits of fire-cracked rocks devoid of artifacts, but containing some charcoal. These rock pits may have served for the ceremonial deposition of debris from the cremation areas. UCLA-246A and 246B are duplicate collections from a fire pit located at the base of the mound near the center, 24 in. depth.

General Comment (F.J.S.) : the three Adena mounds are remarkably similar in age-1825 to $2040 \mathrm{yr}$ (UCLA-241, 242, and 243) — which is consistent with their artifact inventory and their expected position in Adena cultural history. The Hopewell mounds cover a larger time span and may indicate that the Harness Works was occupied, perhaps intermittently, by Hopewell people over a period of some $1700 \mathrm{yr}$ (1000 to 2700 B.P.-UCLA-244, 245, and 246). This conclusion is strengthened by the fact that the three mounds were quite dissimilar in structure and artifact inventory, although typically Hopewell in type.

\section{UCLA-216. Follins Pond, Massachusetts}

$250 \pm 120$

Wood from post in gully near edge of Follins Pond, Massachusetts $\left(41^{\circ}\right.$ $37^{\prime} \mathrm{N}$ Lat, $70^{\circ} 19^{\prime} \mathrm{W}$ Long). Sample related to the possible discovery and attempted colonization of America by the Norsemen, for this was considered as possibly the wintering over base of Leif Eriksson during the three years he and his party spent in "Vinland." Sample from one of the props used for a ship which was beached to avoid damage from winter ice. Nine such props were located, spread evenly over a $58 \mathrm{ft}$ distance which would correspond with the size of the Viking ships and the fact that they had straight keels. Expected age of sample, 1000 yr. Coll. 1952 by M. Robbins of Mass. Arch. Soc.; subm. by O. G. Landsverk, 641 Sonora Ave., Glendale, California. Comment: sample is too young to be related to Leif Eriksson voyages. Confirms "modern" date by Yale Lab., Y-268 (Yale III), which was kindly brought to our attention by E. S. Deevey.

\section{B. Mexico}

\section{UCLA-145. Barra de Navidad, Jalisco, Mexico}

\section{A.D. 1190}

Charcoal from depth of $6 \mathrm{~m}$ in shell mound at Barra de Navidad, Jalisco, Mexico ( $19^{\circ} 50^{\prime} \mathrm{N}$ Lat, $104^{\circ} 43^{\prime} \mathrm{W}$ Long). Site yields pottery, mostly very plain. Coll. by S. Long; subm. by C. W. Meighan. Comment (C.W.M.) : age younger than expected, for on cultural grounds expected age would be older than A.D. 600. Cross-dating on pottery indicates this level to be contemporaneous to the Morett Site, which yields older dates (see samples UCLA-187, 188this date list). 
UCLA-148. Playa del Tesoro, Colima, Mexico

$1430 \pm 100$

A.D. 520

Charcoal from midden at Playa del Tesoro, Colima, Mexico $\left(19^{\circ} 17^{\prime} \mathrm{N}\right.$ Lat, $104^{\circ} 20^{\prime} \mathrm{W}$ Long). Depth 1.4 to $1.6 \mathrm{~m}$ in Pit 1, associated with pottery and clay figurines. Coll. by R. J. Fitzwater; subm. by C. W. Meighan. Comment (C.W.M.) : expected age on cultural association was prior to A.D. 600 . Good agreement with Morett Site date of $1500 \pm 80$ (UCLA-187, this date list) which applies to same kinds of cultural remains.

\section{Morett series, Colima, Mexico}

Morett Site $\left(19^{\circ} \mathrm{N}\right.$ Lat, $105^{\circ} \mathrm{W}$ Long), is situated on the S side of the Rio de Cihuatlan or Marabasco, which constitutes the boundary between the states of Jalisco and Colima. Extensive midden deposits, over $3 \mathrm{~m}$ in depth at some points, are present. A definite stratigraphic sequence is evident in ceramic types, and the major occupation of the site appears to correlate with Isabel Kelly's Tuxacuesco phase from neighboring Jalisco. Coll. by R. J. Crabtree; subm. by H. B. Nicholson, Anthropol. Dept., UCLA.

\section{UCLA-187. Morett Site, depth $1.10 \mathrm{~m}$}

$$
\begin{array}{r}
1500 \\
\text { A.D. } 450
\end{array}
$$

Charcoal from probable hearth at depth of $1.10 \mathrm{~m}$ in Pit 3.

UCLA-188. Morett Site, depth $2.30 \mathrm{~m}$

$$
\begin{gathered}
2100 \pm 90 \\
150 \text { в.C. }
\end{gathered}
$$

Charcoal, scattered pieces from depth of 2.20 to $2.40 \mathrm{~m}$ in Pit 7 . General Comment (H.B.N.) : UCLA-187 should date the final ceramic phase at the site, UCLA-188 the later portion of the earliest phase. The latter date provides the first clear-cut chronological evidence of a late Preclassic or Early Classic occupation of the Mexican $W$ coast by representatives of the advanced Mesoamerican type of culture.

\section{Cuicuilco Pyramid series, Mexico City, Mexico}

Charcoal samples from near the pyramid at Cuicuilco just $\mathrm{S}$ of Mexico City $\left(19^{\circ} 18^{\prime} \mathrm{N}\right.$ Lat, $99^{\circ} 11^{\prime} \mathrm{W}$ Long), and the associated subpedregal mound area (Cuicuilco B) in Peña Pobre quarry $0.3 \mathrm{mi} \mathrm{W}$. The Cuicuilco site was examined earlier by Cummings (1933) and Kroeber (1925), and by Heizer and Bennyhoff (1958) in 1957. The dates reported here are based on charcoal collected 1957-1962, and it was hoped that they would clarify some of the stratigraphic and chronological prohlems of the site. The $\mathrm{C}^{14}$ dates (UCLA-205 to 212 and 228 , this date list) present new problems of archaeological interpretation which cannot be adequately explained in the comments attached to each date. Reference is made in the comments on the individual sample dates to the presently accepted archaeological chronology which places the Early Preclassic at 1500-800 в.C. (Tlalpan at Cuicuilco, Early El Arbolillo and Early Zacatenco phases), Middle Preclassic at 800-400 B.c. (Tlatilco and Middle Zacatenco phases), and Late Preclassic at 400 B.C.-A.D. 100 (Ticoman I-III, Tezoyuca, Chimalhuacan and Tzacualli phases). Coll. 1957-62 by R. F. Heizer, J. A. Bennyhoff, and R. Millon; subm. by R. F. Heizer, Univ. of California, Berkeley. 


\section{UCLA-228. Cuicuilco A-2}

From immediately beneath the thin ash layer on which the pedregal rests, and beneath which is the archaeological deposit. Sample is a root carbonized by action of the lava. Samples from below this layer have given a range of dates: C-200, 2422 士 250, (Chicago I); M-663, $2040 \pm 200 ;$ M-664, 1430 \pm 200 , (Michigan III).

\section{UCLA-205. Cuicuilco B-1}

$$
\begin{array}{r}
1790 \pm 75 \\
\text { A.D. } 160
\end{array}
$$

From Mound 2 at SE corner of Structure II, $1.37 \mathrm{~m}$ below Datum A2 in mixed fill of Structure III. Latest ceramics pertain to the Chimalhuacan phase, but date falls within the later Tzacualli phase.

\section{UCLA-206. Cuicuilco B-2}

$$
1950 \pm 80
$$

From Mound 2, Trench 5, depth $2.3 \mathrm{~m}$ below Datum A2 on Floor 4 of Structure I. This floor appears, from the date, to have been built in Chimalhuacan phase.

\section{UCLA-207. Cuicuilco B-3}

$$
2600 \pm 70
$$

650 B.C.

From Mound 4, Trench 1, $2.75 \mathrm{~m}$ below Datum A4, above clay basin in hearting of structure. Charcoal in basin was associated with Ticoman I ceramics and figurines, but this date is too early for the usually accepted age of beginning Ticoman I at 400 B.c. Since sample was separated by $10 \mathrm{~cm}$ from the older Tlalpan layer below, some mixture may have occurred to give this sample greater age.

\section{UCLA-208. Cuicuilco B-4}

$$
\begin{aligned}
& 2100 \pm 75 \\
& 150 \text { B.C. }
\end{aligned}
$$

From Mound 2, Trench 5, 2.41 m below Datum A2 between Floors 3 and 4. of Structure I. Date suggests Floor 3 was built in Ticoman III phase; ceramics from fill are Middle Zacatenco.

\section{UCLA-209. Cuicuilco B-5}

$$
2300 \pm 70
$$$$
350 \text { в.c. }
$$

From Mound 2, Trench 5, at $2.68 \mathrm{~m}$ below Datum A2 between Floors 2 and 3 of Structure I. Date suggests Floor 2 was built in Ticoman I phase; ceramics from fill are Middle Zacatenco.

\section{UCLA-210. Cuicuilco B-6}

$3980 \pm 60$

\section{0 в.c.}

From Mound 1, Trench 4, at $4.0 \mathrm{~m}$ below Datum Al. Charcoal collected in sterile structure fill layers apparently laid down in Middle Zacatenco times. It is highly unlikely that this phase can date (as sample would suggest) from 1000 yr earlier than other archaeological evidence indicates. The charcoal may come from Tlalpan phase refuse laid down as structure fill in Zacatenco times. Probably reason for early date is due to the use of older refuse which may be either Tlalpan phase or pre-ceramic (if absence of pottery is taken as a guide). There exist early $\mathrm{C}^{14}$ dates for Early Zacatenco (1358 в.c.) and Early Tlatilco (1455 в.c.) which are regarded by some archaeologists as too early. If, how- 
ever, these are correct, the UCLA-210 and 212 dates may be correct if they refer to the earliest phase at Cuicuilco (i.e. Tlalpan). Only further excavation, more dates, and archaeological analysis can settle this question.

UCLA-211. Cuicuilco B-7

$6715 \pm 90$

4765 в.c.

From Mound 1, near Trench 9, at $5.39 \mathrm{~m}$ below Datum Al. Date of this sample is too old for it to refer to the ceramic period. Sample came from charcoal-bearing fill lacking pottery (i.e. from pre-ceramic times?) but which seems to have been laid down in Middle Zacatenco phase.

\section{UCLA-212. Cuicuilco B-8}

$4050 \pm 75$

2100 B.c.

From Mound 1, Trench 1, at $5.86 \mathrm{~m}$ below Datum Al. Fill layer which produced charcoal for this date may have been laid down either in Tlalpan or Middle Zacatenco times. The date, while early, may give correct age of the Tlalpan phase which is Early Preclassic. Unfortunately the one undoubted charcoal sample of Tlalpan phase, which was secured from the bottom of Cummings' "shaft" just S of the round pyramid in the Cuicuilco A zone, was lost in the UCLA laboratory and the reliability of UCLA-212 and age of Tlalpan phase must await collection of additional charcoal.

General Comment (R.F.H.) : UCLA-228 is presumed to date the eruption of Xitli volcano whose lava covered the already abandoned site of Cuicuilco, but seems too young by 200 to $300 \mathrm{yr}$. Samples C-200 (2422 \pm 250 , Chicago I) and M-663 (2040 \pm 200 , Michigan III) came from the Cuicuilco archaeological deposits and therefore predate the eruption by some undetermined amount of time. Sample Y-437 (1925 \pm 60 , Yale IV) probably does not date eruption, since it seems to refer to the prepedregal archaeological deposit containing Ticoman pottery. Sample M-664 (1430 \pm 200 , Michigan III) is also a preeruption archaeological date, but seems too young in any event for the Ticoman phase at Cuicuilco. Mound 1 (a terraced platform structure) is older than the other mounds (which also contain structures) in the Cuicuilco B site area. This conclusion, arrived at on the basis of ceramics, is borne out even if the oldest dates (UCLA-210, 211, 212) are ignored, because they refer to structure fills derived from pre-ceramic refuse deposits which were transported to the site from their original location.

\section{Central and South America}

\section{Tikal series, Guatemala}

Wood samples from Mayan temples at Tikal ( $17^{\circ} 13.3^{\prime} \mathrm{N}$ Lat, $89^{\circ} 38.5^{\prime}$ W Long), Petén, Guatemala, to check on correlations of the Mayan and Christian calendars. Samples were from lintel and vault beams and, where possible, precautions were taken to avoid "post-sample growth" errors. Subm. by Linton Satterthwaite, University Mus., Philadelphia.

UCLA-159A. Tikal, Temple IV

$1258 \pm 40$

A.D. 692

Room 3, Vault Beam 2, Mus. No. T-275. Univ. of Pa. C ${ }^{14}$ No. P-243. 
UCLA-159B. Tikal, Temple IV

Lintel 3, Mus. No. T-478. Univ. of Pa. C ${ }^{14}$ No. P-248.

UCLA-158A. Tikal, Structure 10

Vault Beam A/8, Mus. No. T-551.

UCLA-158B. Tikal, Structure 10

Vault Beam 9, Mus. No. T-552.

UCLA-158C. Tikal, Structure 10

Vault Beam 10, Mus. No. T-553.

UCLA-158D. Tikal, Structure 10

Lintel 34, Beam A, Mus. No. T-600.

UCLA-158E. Tikal, Structure 10

Lintel, Beam B, Mus. No. T-602.

General Comment: the $\mathrm{C}^{14}$ dates on Temple IV support the Goodman-Thompson correlation while those on Structure 10 fall between the Goodman-Thompson and Spinden correlations. These results can be compared with the Tikal series dated by the Univ. of Pennsylvania (Satterthwaite and Ralph, 1960). For comparison of these samples the half life error has not been included in errors quoted below.

Average of UCLA-159A and 159B which are duplicate samples of P-243 and P-248

Average of 10 samples dated by Univ. of Pennsylvania, P-235 to P-249

Average of UCLA-158 series

Univ. of Pennsylvania P-293
$1217 \pm 45$

A.D. 733

$1335 \pm 40$

A.D. 615

$1304 \pm 60$

A.D. 646

A.D. 584

A.D. 632

$1303 \pm 50$

A.D. 647

$$
\begin{array}{rlr} 
& = & \text { A.D. } 746 \pm 16 \\
\text { Difference } & = & 34 \pm 34 \mathrm{yr} \\
\cline { 2 - 3 } & = & \text { A.D. } 625 \pm 25 \\
& = & \text { A.D. } 606 \pm 45 \\
\text { Difference } & = & 19 \pm 50 \mathrm{yr}
\end{array}
$$

Univ. of Penssylvania P. 293

The agreement between the two laboratories is good, especially considering that the Pennsylvania ages were computed using pre-1900 Oak wood as the modern standard and the UCLA ages were computed on basis of 0.95 NBS oxalic acid. The agreement is also additional support for the validity of 0.95 NBS oxalic acid as a $\mathrm{C}^{14}$ standard for the contemporary activity of the biosphere.

If the samples measured are representative of the contemporary biosphere of that period, it would appear that Structure 10 is ca. $100 \mathrm{yr}$ older than Temple IV.

However, variations of up to $\pm 2 \%$ between $\mathrm{C}^{14}$ ages and calendar ages of tree rings have been reported by many workers. The reason for the discrepancy is not clear. This problem thus introduces some uncertainty when really precise $\mathrm{C}^{14}$ dating, corresponding to variations of less than $1 \%$ in $\mathrm{C}^{14}$ activity 
is attempted. Finding the cause of this scatter in tree-ring data would appear to be the next most vital step in improving the precision of $\mathrm{C}^{14}$ dating for samples less than a few thousand years old.

The possibility that $\mathrm{C}^{14}$ dates for the Mayan period could be in error due to a slow change in the $\mathrm{C}^{14}$ activity of the contemporary biosphere has been minimized by the series of six known age woods of the period A.D. 560 to 900 recently measured by Ralph (1961). The average calendar age of these six samples was A.D. 719 while the average $\mathrm{C}^{14}$ age obtained was A.D. $729 \pm 29$.

\section{Gatun Lake series, Panama}

Sediments from various depths in the sedimentary complex filling the Gatun Basin which is the lowest physiographic area in the Isthmus of Panama. It seems probable that the basin was slowly filling as a result of rising worldwide sealevel during the melting of the Pleistocene ice sheets. Coll. by Panama Canal Co.; subm. by E. S. Barghoorn, Harvard Univ., Cambridge, Massachusetts.

UCLA-183. Gatun Lake Sediments

$$
7300 \pm 130
$$

Wood fragments from Panama Canal Co. core SL-52, depth $43 \mathrm{ft}$ below mean sealevel $\left(9^{\circ} 11^{\prime}+365^{\prime} \mathrm{N}\right.$ Lat, $79^{\circ} 53^{\prime}+911^{\prime}$ W Long $)$.

\section{UCLA-184. Gatun Lake Sediments}

$8560 \pm 130$

6610 в.c.

Wood fragments from Panama Canal Co. core SL-48, depth $66 \mathrm{ft}$ below mean sealevel $\left(9^{\circ} 11^{\prime}+1331^{\prime} \mathrm{N}\right.$ Lat, $79^{\circ} 55^{\prime}+4501^{\prime} \mathrm{W}$ Long $)$.

UCLA-185. Gatun Lake Sediments

$9600 \pm 300$

7650 в.с.

Mineral peat from Panama Canal Co. core SL-103, depth $109 \mathrm{ft}$ below mean sealevel $\left(9^{\circ} 16^{\prime}+4945^{\prime} \mathrm{N}\right.$ Lat, $79^{\circ} 52^{\prime}+2963^{\prime}$ W Long $)$.

\section{UCLA-186. Gatun Lake Sediments}

$$
11,300 \pm 200
$$

Wood fragments from Panama Canal Co. core SL-103, depth $158 \mathrm{ft}$ below mean sealevel $\left(9^{\circ} 16^{\prime}+5945^{\prime} \mathrm{N}\right.$ Lat, $79^{\circ} 52^{\prime}+2963^{\prime} \mathrm{W}$ Long $)$.

General Comment (E.S.B.) : dates fit well with predicted postglacial sealevel rise; and as there is no reason to assume, on geologic grounds, that the Isthmus of Panama has been submerging, it appear that the filling of the basin has been under sealevel rise control. Rate of rise of sealevel represented in the Panama dates also fits well with comparable data from the Gulf coast of the United States and from the Atlantic coast of the New England area.

\section{Hacha series, Acari Valley, Peru}

The Hacha Site in the Acari Valley, Peru (15 $28^{\prime} 42^{\prime \prime} \mathrm{S}$ Lat, $74^{\circ} 37^{\prime} 36^{\prime \prime}$ W Long), is adjacent to an old river channel, now dry, in the desert behind the Hacienda Cerro Colorado on the $\mathrm{E}$ side of the river. At this site a very distinctive style of pottery occurs which is considered to be the earliest pottery yet found in southern Peru. 


\section{UCLA-153. Hacha Style Pottery}

Wood charcoal from shell refuse containing Hacha style sherds. Coll. by G. S. Vescelius, Hernán Amat, and Dorothy Menzel; subm. by J. H. Rowe, Univ. of California, Berkeley.

\section{UCLA-154. Hacha Style Architecture}

Carbonized seeds, embedded in top of clay floor under sand fill containing scattered marine shells and Hacha style sherds. Associated with ashes and discoloration of the clay indicating that a fire had been built on the floor. Coll. and subm. by J. H. Rowe. Comment (J.H.R.) : both dates acceptable; samples are from different parts of the site and need not be exactly the same age.

\section{Ancon series, Peru}

Samples from excavations of campsites near Ancon, Peru. Coll. by E. P. Lanning; subm. by J. H. Rowe, Univ. of California, Berkeley.

\section{UCLA-201. Bay of Ancon}

Charcoal (Tillandsia) from site (PV 45-29B) on Pampa de Piedras Gordas near the Bay of Ancon, $32 \mathrm{~km} \mathrm{~N}$ of Lima (11 $48^{\prime} \mathrm{S}$ Lat, $77^{\circ} 8^{\prime} \mathrm{W}$ Long). Comes from a deposit of shallow ash-stained sand containing numerous land snail shells from extinct lomas vegetation, small numbers of sea shells, and burnt Tillandsia stems and leaves. Though not from a normal refuse deposit, sample should date the Piedras Gordas Complex, thought to be the earliest of six lithic industries found around the Bay of Ancon. The lithic industry consists of core tools, large flakes, and a few scrapers and grinding tools.

\section{UCLA-202. Ancon-Chillon}

$$
\begin{aligned}
& \mathbf{7 1 4 0} \pm 100 \\
& \mathbf{5 1 9 0} \text { в.c. }
\end{aligned}
$$

Charcoal from site (PV 45-84) on the Ancon-Chillon watershed $29 \mathrm{~km}$ $\mathrm{N}$ of Lima $\left(11^{\circ} 50^{\prime} 30^{\prime \prime} \mathrm{S}\right.$ Lat, $77^{\circ} 7^{\prime} \mathrm{W}$ Long), separated from the Pampa de Piedras Gordas by a group of low hills. Sample was Tillandsia charcoal from the lower half of a fireplace containing burnt stones, sea shells, and the charcoal. It should date the Luz Complex, thought to be the second of the lithic industries at Ancon, characterized by stemmed projectile points and thick hifacial blades of Paiján type.

\section{UCLA-203. Loma Ancon}

Charcoal from site (PV 45-31) on the slope of Loma Ancon overlooking the Pampa del Canario near Ancon ( $11^{\circ} 38^{\prime} \mathrm{S}$ Lat, $77^{\circ} 8^{\prime} 30^{\prime \prime} \mathrm{W}$ Long). Sample was Tillandsia charcoal from the lower part of an ancient fireplace containing burnt stones, sea shells, and the charcoal. The artifacts from this site belong to the Canario Complex, identified by its flat bi-pointed projectile points similar to one from Santa Isabel Ixtapan in Mexico.

General Comment (J.H.R.) : all three dates are too recent to fit other South American $\mathrm{C}^{14}$ dates; UCLA-201 and 202 are too close together. 


$$
\text { D. Africa }
$$

\section{Luembe River series, Angola}

Samples taken from sections exposed by mining operations in the buried channel of the Luembe River, Angola, at the Mufo Mine and from creek bed level or below at the Calunda 3 and Furi I mine; related to culture sequences of this region. Coll. 1960 and subm. by J. D. Clark, Anthropol. Dept., Univ. of California, Berkeley.

\section{UCLA-170. Furi I Mine}

$1800 \pm 80$

\section{A.D. 150}

Wood from lower stream gravel post-Pleistocene. Late Tshitolian Culture. Tools and potsherds indicating resorting in Iron Age times.

UCLA-171. Calunda 3 Mine

$4700 \pm 100$

2750 в.c.

Wood from lower stream gravel. post-Pleistocene. Late Tshitolian Culture.

\section{UCLA-167. Mufo Mine}

$6830 \pm 120$

Wood from Upper Sand Bed in Flats Terrace at depth $5 \mathrm{ft}$. Early postPleistocene. Tshitolian Culture. Represents the aggradation of the post-Pleistocene Makalian Wet Phase.

\section{UCLA-172. Calunda 3 Mine}

$12,970 \pm 250$

11,020 в.c.

Charcoal from lower part of Redistributed Sands IV over lower stream gravel. Early post-Pleistocene. Lower Tshitolian Culture.

UCLA-168. Mufo Mine

$38,000 \pm 2500$ 36,050 в.c.

Peat from sand layer in Lower Flats Gravel of Flats Terrace at depth of $10 \mathrm{ft}$. Early Upper Pleistocene. Lower Lupemban Culture.

\section{UCLA-169. Mufo Mine}

Wood from sand layer near base of Lower Flats Gravel of Flats Terrace at depth of $15 \mathrm{ft}$. Early Upper Pleistocene. Lower Lupemban Culture.

General Comment (J.D.C.) : the Upper Pleistocene age of the gravels filling the buried channel of the Flats Terrace of the Luembe River is confirmed by UCLA-168 and UCLA-169, which also date the Lower Lupemban Culture to the closing stage of the early Gamblian Pluvial. This is consistent with the age of the Late Acheulian and Sangoan Cultures at the Kalambo Falls from which the Lupemban evolved. The date of UCLA-172 is somewhat older than anticipated although it is consistent with what is believed to be the same surface at Mufo dated as 11,189 $\pm 490,(\mathrm{C}$-580, Chicago II). It indicates that a microblade element was present in the cultures of the Congo Basin by terminal Pleistocene times. UCLA-167 confirms the estimated age of this bed and of the Makalian Wet Phase. UCLA-171 and UCLA-170 date the formation of the lower gravels of the stream courses and indicate that these were sometimes resorted in Early Iron Age times. 


\section{Kalomo series, Northern Rhodesia}

Samples from excavations at Isamu Pate Mound, an early Iron Age occupation mound, Kalomo, Northern Rhodesia. Coll. 1960 by B. M. Fagan; subm. by J. D. Clark.

UCLA-175. Kalomo, depth 15 in.

Charcoal from posthole. Strip 1, Square A2.

UCLA-176. Kalomo, depth 40 in.
$710 \pm 50$

A.D. 1240

$890 \pm 70$

Charcoal from burnt log from a hearth. Strip 1, Square B1.

UCLA-177. Kalomo, depth 73 in.

$960 \pm 70$

Charcoal from remains of a hearth. Strip 1, Square A5.

General Comment (J.D.C.) : Isamu Pate is the type-site for the Kalomo Culture which was practiced by the Early Iron Age inhabitants of the plateau country between the Zambezi and Kafue Rivers. The midden refuse indicates a mixed farming economy with emphasis on hunting in the earlier stages. These dates successfully confirm the estimated duration of this culture which is in part derived from the Situmpa Culture (= Channelled Ware pottery) dating in the range A.D. 0-200 and in part intrusive.

\section{Lochinvar series, Northern Rhodesia}

Lochinvar hot spring mound is a Late Stone Age site on the edge of the Kafue river basin $27 \mathrm{mi} \mathrm{NW}$ of Monze, Northern Rhodesia. Cultural deposits within the mound cover a depth of over $8 \mathrm{ft}$ and include a Wilton stone industry, shell beads, charcoal, animal bone, nuts and seeds of edible vegetation, at least one wooden implement and the remains of five of the human occupants. There were no post-Later-Stone-Age materials whatsoever. Coll. 1960 by C. Gabel; subm. by J. D. Clark.

\section{UCLA-174. Lochinvar, depth $5 \mathrm{ft}$}

$4700 \pm 100$

Wood from depth of $5 \mathrm{ft}$, associated with human skeleton.

\section{UCLA-173. Lochinvar, depth 8 ft}

Charcoal from depth of $8 \mathrm{ft}$, in association with fossil fauna, Later Stone Age implements, and a wooden digging stick. Comment: dates are not in stratigraphic order. Further samples will need to be run to see if this is due to contamination or intrusive material.

\section{E. Pacific Ocean}

UCLA-193. Isle of Pines, New Caledonia

Shell (Tridacna) from $11 \mathrm{ft}$ above mean sealevel, Kuto Pt., Isle of Pines, New Caledonia $\left(22^{\circ} 40^{\prime} \mathrm{S}\right.$ Lat, $167^{\circ} 27^{\prime} \mathrm{E}$ Long). Shell was broken out of the flat surface of an elevated coral reef-this surface extends for ca. 0.5 mi. Coll. by F. P. Shepard; subm. by C. L. Hubbs. 
UCLA-194. Tuoho, New Caledonia

Shell (Tridacna) from Tuoho, New Caledonia $\left(20^{\circ} 45^{\prime} \mathrm{S}\right.$ Lat, $165^{\circ} 15^{\prime}$ E Long). Shell broken from reef at high tide level, which is $3 \mathrm{ft}$ above low tide level. Indicates a fall of sealevel compared to the reef of at least $3 \mathrm{ft}$ over the last 5000 yr. Coll. by F. P. Shepard; subm. by C. L. Hubbs.

UCLA-146. Atta-Baru, Okinawa

$3370 \pm 80$

1420 в.c.

Charcoal from Atta-Baru shell mound, Okinawa $\left(26^{\circ} 30^{\prime} \mathrm{N} \mathrm{Lat,} 128^{\circ} \mathrm{E}\right.$ Long), Pit H, depth 36 to 42 in. Coll. by H. Takamiya; subm. by C. W. Meighan. Comment (C.W.M.) : no other $\mathrm{C}^{14}$ dates are known for the Ryukyu Islands. Stylistic cross-ties with Japanese finds indicated age to be in B.c. period.

\section{F. England}

\section{UCLA-113. Underground Temple, Thanet, England \\ $280 \pm 100$}

Piece of shell mosaic from $\mathrm{E}$ wall of underground shrine located in Thanet, England $\left(51^{\circ} 23^{\prime} \mathrm{N}\right.$ Lat, $1^{\circ} 20^{\prime} \mathrm{E}$ Long). The temple contains ca. 100 panels of shell mosaic. Its design consists of a Shrine with an altar in the $\mathrm{S}$, the upper part of which forms a 5-rayed Sun. This leads out into a winding passage $30 \mathrm{ft}$ long, a Dome with three Alcoves, and a Rotunda with two 4-ft passage ways surrounding and a passage leading up to the surface in the $\mathrm{N}$. Extensive renovations and replacement of shell mosaic have taken place in the past, chief of which were the removal of the domed and arched roof of the Shrine after the discovery in 1835. Subm. by Conan Shaw, Angmering Village, Sussex.

\section{Cruck-Framed House series, England}

The cruck-framed house or barn is one in which the principal trusses supporting the roof consist of pairs of heavy timbers which have a curvature or elbow such that each pair meets at the roof ridge. Variant forms are base crucks in which the feet rest on a stone plinth near ground level and upper crucks which rest just below the wall-plate level. The cruck as a form of timberframe construction has survived in a few houses and barns of medieval date in several counties of England and Wales (Smith, 1960); by the 14th century, crucks were becoming obsolete except for barns and humble dwellings. There is little historical evidence regarding the antiquity of English crucks, the earliest that can be dated with any certainty being 1382. As this type of framework was brought to England from Northern Europe in pre-Norman times and possibly by the Angles as early as the 6th century, survivals from early medieval times are possible.

Samples from base crucks have been collected from two counties, Derbyshire and Berkshire: the former has a dense distribution of crucks and is on one of the lines of Anglian penetration into England; the latter includes numerous agricultural villages in which various dwellings have persisted from medieval times. 


\section{Derbyshire County series}

Coll. 1962 by B. Bunker; subm. by J. M. Fletcher, "Willowbrook," Harwell, Berks.

\section{UCLA-232. Whittington Farm, Chesterfield}

$$
425 \pm 65
$$

\section{A.D. 1525}

Oak, heartwood, from one of the 5 oak crucks, in the house known as "Whittington Farm, Whittington Moor," which was dismantled in 1961. Location (53 $15^{\prime} \mathrm{N}$ Lat, $1^{\circ} 25^{\prime} \mathrm{W}$ Long), $2 \mathrm{mi} \mathrm{N}$ of Chesterfield, and $200 \mathrm{yds}$ $\mathrm{W}$ of a place on the River Rother where several ancient bridle paths converged.

\section{UCLA-233. Cartledge Hall, Holmesfield}

A.D. 1745

$205 \pm 65$

Oak sap-wood from cruck barn at Cartledge Hall, Holmesfield.

\section{Berkshire County series}

Coll. 1962 and subm. by M. C. and J. M. Fletcher.

\section{UCLA-235. Church Lane, Harwell}

$565 \pm 65$

A.D. 1385

Oak, taken inside the house, at $3 \mathrm{ft}$ from the base of end cruck (Fletcher, 1962) at Le Carillon, Church Lane, Harwell $\left(51^{\circ} 36^{\prime} \mathrm{N}\right.$ Lat, $1^{\circ} 17^{\prime} \mathrm{W}$ Long), 100 yds $\mathbb{W}$ of Church.

\section{UCLA-236. Jennings Lane, Harwell}

$$
410 \pm 65
$$

\section{A.D. 1540}

Oak, heartwood, from internal cruck at $8 \mathrm{ft}$ from base in School House, Jennings Lane, Harwell. The crucks in this house are large and have mortice and tenon joints indicating post A.D. 1200 date.

\section{UCLA-267. Church Lane, Harwell}

$$
525 \pm 60
$$

\section{A.D. 1425}

Oak from end cruck at $\mathrm{W}$ end of Dell Cottage, Church Lane, Harwell. Tie beams or collars halved to blades, no mortice and tenon joints. Should pre-date UCLA-236.

\section{UCLA-239. Harwell Church, Harwell}

$$
445 \pm 60
$$

A.D. 1505

Wood from part of oak tie-beam removed in 1962 from roof of N Transept of Harwell Church due to attack by deathwatch beetle. Style of timbered roof construction in this transept is typical of local 14th and early 15th century work.

UCLA-238. Church Farm, Long Whittenham 560
A.D. 1390

Oak, probably heartwood, from part of ancient cruck (Portman, 1956) embedded internally in modern brick part of Church Farm, Long Wittenham ( $51^{\circ} 38^{\prime} \mathrm{N}$ Lat, $1^{\circ} 12^{\prime} \mathrm{W}$ Long) .

UCLA-237. Tractor Shed, Long Wittenham A.D. $1510 \pm 60$

UCLA-265. Tractor Shed, Long Wittenham $425 \pm 60$

A.D. 1525 
UCLA-266. Tractor Shed, Long Wittenham

$410 \pm 60$

Oak, mainly sapwood, from crucks in cottage (now converted to tractor shed), adjacent to Church Farm, Long Wittenham. Outer surface of sample planed to remove paint. UCLA-265 is from an internal cruck, while UCLA-237 and 266 are duplicate collections from inside of cruck at NE corner of building.

\section{Buhen series, Egypt}

\section{G. Egypt}

Charcoal samples from Buhen on the $W$ bank of the Nile opposite Wadi Halfa in Northern Sudan (21 $54^{\prime} \mathrm{N}$ Lat, $31^{\circ} 17^{\prime} \mathrm{E}$ Long). Coll. 1962 by W. B. Emery of the Egypt Exploration Soc.; subm. by I. E. S. Edwards, Keeper of Egyptian Antiquities, British Mus., London.

\section{UCLA-247. Buhen, Block 16 \\ $4060 \pm 60$ \\ 2110 в.c.}

Wood charcoal from Building Block 16 (Trench). Estimated age preFourth Dynasty (before 2600 B.c. or 4550 B.P.). Comment: sample is younger than UCLA-248 which is definitely Fourth to Fifth Dynasty.

\section{UCLA-248. Buhen, Block 1} ing the chealings bearing the names of the Kings of the Fourth and Fifth Dynasties (ca. 2600-2350 B.C.). Comment: checks well with expected age of 4300 to 4550 B.P. Age based on new $\mathrm{C}^{14}$ half life of $5730 \mathrm{yr}$ would be $4560 \pm 80$.

Date lists:

\section{REFERENCES}

$\begin{array}{ll}\text { Chicago I } & \text { Arnold and Libby, 1951 } \\ \text { Chicago II } & \text { Libby, 1951 } \\ \text { Lamont IV } & \text { Broecker and Kulp, 1957 } \\ \text { Michigan III } & \text { Crane and Griffin, 1958 } \\ \text { UCLA I } & \text { Fergusson and Libby, 1962 } \\ \text { Yale III } & \text { Barendsen, Deevey and Gralenski, 1957 } \\ \text { Yale IV } & \text { Deevey, Gralenski and Hoffren, 1959 }\end{array}$

Arnold, J. R., and Libby, W. F., 1951, Radiocarbon dates: Science, v. 113, p. 111-120.

Barendsen, G. W., Deevey, E. S., and Gralenski, L. J., 1957, Yale natural radiocarbon measurements III: Science, v. 126, p. 908-919.

Broecker, W. S., and Kulp, J. L., 1957, Lamont natural radiocarbon measurements IV: Science, v. 126, p. 1324-1334.

Bryan, K., and Toulouse, J. H., 1943, The San Jose non-ceramic culture and its relation to Puebloan culture in New Mexico: Am. Antiquity, v. 8, n. 3, p. 269-280.

Butler, B. R., 1961, The old Cordilleran culture in the Pacific Northwest: Pocatello, Idaho State Coll. Mus. Occasional Papers, no. 5.

Chaney, R. W., and Mason, H. L., 1934, A Pleistocene flora from Santa Cruz Island: Carnegie Inst. Publ. no. 415, p. 1-24.

Crane, H. R., and Griffin, J. B., 1958, University of Michigan radiocarbon dates III: Science, v. 128 , p. 1117-1123.

Cummings, B., 1933, Cuicuilco and the Archaic culture of Mexico: Arizona Univ., Soc. Sci. Bull., v. 4 , no. 8.

Deevey, E. S., Gralenski, L. J., and Hoffren, V., 1959, Yale natural radiocarbon measurements IV: Am. Jour. Sci. Radioc. Supp., v. i, p. 144-172.

Fergusson, G. J., and Libby, W. F., 1962, UCLA radiocarbon dates I: Radiocarbon, v. 4, p. 109-114. 
Fletcher, J. F., 1962, Cruck Cottage in Church Lane, Harwell: Oxoniensia, v. 26, p. $207-$ 214.

Godwin, H., 1962, Half-life of radiocarbon: Nature, v. 195, p. 984.

Heizer, R. F., and Bennyhoff, J. A., 1958, Archaeological investigation of Cuicuilco, Valley of Mexico, 1957: Science, v. 127, p. 232-233.

Kroeber, A. L., 1925, Archaic culture horizons in the Valley of Mexico: Univ. of California Publs. in Am. Archeol. and Ethnology, v. 17, p. 373-408.

Libby, W. F., 1951, Radiocarbon dates II: Science, v. 114, p. 291-296.

Meighan, C. W., and Eberhart, H., 1953, Archaeological resources of San Nicolas Island, California: Am. Antiquity, v. 19, p. 109-125.

Orr, P. C., 1956, Radiocarbon dates from Santa Rosa Island I: Santa Barbara Mus. Nat. History, Dept. Anthropol. Bull. 2, p. 1-10. 1960a, Radiocarbon dates from Santa Rosa Island II: Santa Barbara Mus. Nat. History, Dept. Anthropol. Bull. 2, 12 p.

1960b, Late Pleistocene marine terraces on Santa Rosa Island, California: Geol. Soc. America Bull., v. 71, p. 1113-1120.

Portman, D., 1956, Cruck Houses in Long Wittenham: Berkshire Archaeol. Jour., v. 56,

p. 35-45.
Ralph, E. K., 1961, Radiocarbon "effective" half-life for Maya calendar correlations: Am. Antiquity, v. 27, p. 229-230.

Reinman, F. M., and Townsend, S. J., 1960, Six burial sites on San Nicolas Island, California: Archaeol. Survey, UCLA, Annual Report for 1959-60, p. 1-134.

Satterthwaite, L., and Ralph, E. K., 1960, New radiocarbon dates and the Maya correlation problem: Am. Antiquity, v. 26, p. 165-184.

Smith, J. T., 1960, Medieval Roofs-A Classification: Archaeol. Jour., v. 115, p. 111-149. 